\title{
CFRP による既存構造物の耐震補強工法 ${ }^{\dagger}$
}

\author{
小畠 克 朗*

\begin{abstract}
A Seismic Retrofitting Method Using CFRP for Existing Reinforced Concrete Structures
\end{abstract}

by

\author{
Yoshiro KobataKe*
}

\section{1 まえがき}

構造物の地震に対する設計法は, 地震被害を教訓とし て段階的に発達してきた. 建築物では, 十勝沖地震や宮 城県沖地震等の教訓も生かした新しい耐震設計法, いわ ゆる “新耐震”を導入した建築基準法・同施行令の大改 定が 1981 年に施行された。一方, 道路橋では, 1980 年 に道路橋示方書耐震設計編が制定された。これらの基規 準改定以前に建設された構造物 (“既存不適格構造物” と呼ばれる）の耐震補強の必要性が指摘されていたが, 伸展しなかったのが実状であった.

既存構造物の耐震補強には, 鉄筋コンクリートや鋼材 が一般的に使用され，耐震壁や鉄骨ブレースの増設，柱 の鉄板巻きによる補強などが行われている.これらの補 強工法の問題点を解決する方法として考案したのが, CFRPによる耐震補強工法である。この工法は, 鉄筋 と比較して引張強度が高く, 軽量で耐久性があるなどの 特徴を有する炭素繊維を活用したものである.

1995 年の阪神・淡路大震災では, 多くの構造物が被 害を受けた. 特に，倒壊など深刻な被害を受けたのは， 既存不適格構造物であった. これらの構造物の地震に対 する安全性向上対策の社会的要請が, 今回の大震災を契 機としてょり高まった. そして，炭素繊維の既存構造物 の補修・補強への適用が注目され，この分野での施工実 績が飛躍的に増大している.

土木建築分野では，鉄とコンクリートが構造材料とし て使用されており，CFRP は特殊な新しい構造材料で ある. CFRP とこれを用いた構造物はJIS や JASS 化 されていないため, 建築基準法第 38 条の特殊な材料あ るいは構法に該当し, 基準法上は建設大臣の認定が必要 となる，そのため，官界・学会・民間の各分野でいろい ろな研究開発が実施された。

CFRP による耐震補強工法の技術的な検討課題とし ては, 炭素繊維と CFRP の規格や品質管理, 構造性能 の把握や設計法の確立, 防・耐火性能や耐久性の確保, 施工法とその管理法などである.これらの課題について は, 数多くの補強効果確認実験や各種の試験を行って検 討されており，施工例も多数報告されている。 また， CFRP による既存の建築の柱と煙突の耐震補強につい
ては，(財) 日本建築防災協会から技術評価を取得してい るものもある.

ここでは，CFRP による既存構造物の耐震補強工法 の概要を紹介し, CFRP の材料諸特性の評価法とその 品質管理について述べる.

\section{CFRP 耐震補強工法の概要}

既存構造物の耐震補強で一般的に用いられている炭素 纎維は, 直径が 7 14 $\mu \mathrm{m}$ の連続緘維で高強度・高弾性 のもので, ピッチ系と PAN 系の両方がある. 炭素緎維 の引張力と伸び (ひずみ) との関係を, アラミド繊維, ガラス繊維，および鉄筋と比較したものを図 1 に示す. CFRP の力学的な特徴は, 強度が鉄筋と比較して非常 に高く, 弾性係数が他の纎維よりも高く鉄筋とほぼ同じ であるが，鉄筋に見られるような降伏現象はなく伸びが 小さいことである. 一方, 機能的な特徽は, 鉄筋と比較 して軽量で, 錆びないので耐久性に優れており, 炭素繊 維の状態では柔軟性もあることである. なお, 炭素繊維 の弾性係数はアラミド繊維と比較して大きく, 巻き付け た炭素繊維がコンクリートを拘束する効果がアラミド繊 維よりも高い. そのため, 既存構造物の耐震補強に使用 される繊維は, ほとんど炭素繊維であったが, アラミド 繊維も最近になってごく僅か使用され始めている.

炭素繊維は, エポキシ樹脂を含浸し硬化させた, CFRP の状態で強度を発揮する. 施工時には, 樹脂が 未硬化の炭素繊維の場合と CFRP の場合の 2 種類があ る. 後者は最近開発されたもので例が少なく, 柔軟性の ある炭素纎維の状態で施工できる前者がほとんである. 前者の炭素繊維の製品形態は, 図 2 に示すように, (1)

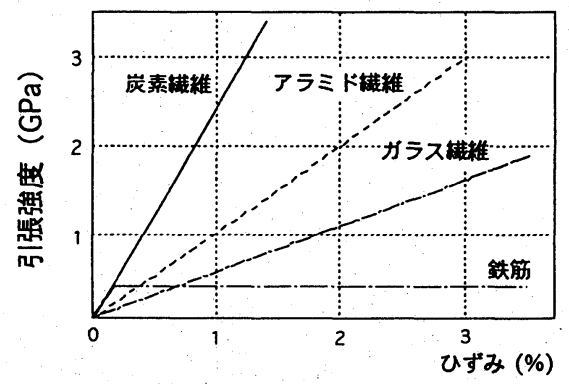

図 1 各種材料の応力 ひずみ関係の比較 
緘維を束ねて系状にした“炭素瀻維ストランド”と，(2) 瀻維を一方向に敷き並べてシート状にした “炭素瀻維シ ート”の 2 種類であるが，(2)を使用する場合が多い。

炭素瀻維を用いた既存構造物の補強は, 基本的には次 の 2 種類となる。

(a) “せん断補強”; コンクリート表而の部材軸と直角 方向に, 炭素瀻維ストランドまたは炭素瀻維シートを巻 き付け，せん断ひび割れが開くのを拘束し，せん断破壞 を防止する補強である(図3参照)。

(b) “曲げ補強” ; コンクリート表面の部材軸方向に炭 素瀻維シートを貼り付け, 部材が折れる曲げ破壊を防止 する補強である (図 4 参照).

せん断補強した部材は，巻き付けた CFRP がコンク リートを拘束するため, コンクリートの圧縮強度向上や 破壞ひずみ増大の効果を期待できる場合がある。この効 果によって，曲げ破壞する部材の破壊までの変形を大き くし，粘り強さ (じん性)を発揮させることができる. じん性を発揮させる補強をじん性補強と呼んでいるが, この解説では, せん断補強にじん性補強を含めて述べて いる.

既存構造物の耐震補強は, せん断補強と曲げ補強の単

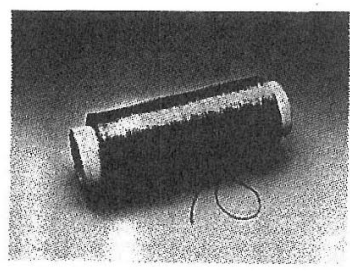

炭素繊維ストランド

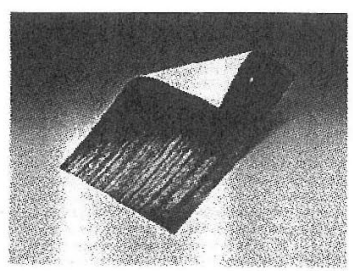

炭素繊維シートト
図 2 使用炭素繊維の製品形態

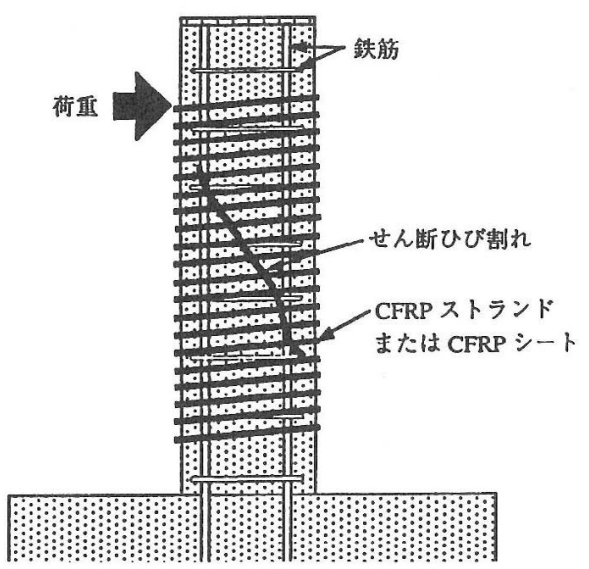

図 3 せん断補強のメカニズム

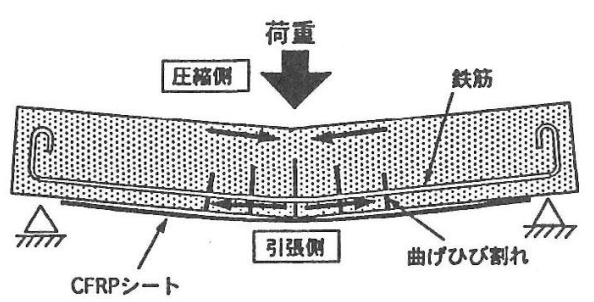

図 4 曲げ補強のメカニズム
独またはそれらの組み合わせとなる。補強対象は，建築 構造物や土木構造物など非常に多くのものがある。ここ では，代表的な建築の柱，煙突，抢よび橋脚の耐震補強 について，それらの概要を紹介する。

\section{$2 \cdot 1$ 建築の柱の耐震補強}

柱は，せん断補強筋（帯鉄筋）量が少ない場合に，ぜ い性的なせん断破壊をすることがある（図５）。柱の耐 震補強は，炭素繊維ストランドをエポキシ樹脂を含浸さ せながら，あるいは，炭素繊維シートをエポキシ樹脂を 用いて貼り付ける要領で，柱の外表面に巻き付けて前記 (a)のせん断補強を行う（図 6 )。この補強は，せん断破 壊を防止し，柱の両端部を曲げ破壤させることによって， 柱を大きく変形させ地震力に抵抗する方法である。

\section{$2 \cdot 2$ 煙突の耐震補強}

煙突は，主鉄筋（曲げ補強筋）量が少ない場合に，地 盤から高さの $2 / 3$ 前後の位置で曲げ破壊することがあ る(図 7 )。煙突の耐震補強は, 炭素繊維シートを煙突 の外表面の高さ (主鉄筋) 方向に，エポキシ樹脂を用い て貼り付ける前記 (b) の曲げ補強を行うとともに，その 外側の水平 (横鉄筋) 方向に，炭素繊維ストランドまた は炭素纎維シートを，柱と同じ要領で巻き付けるもので ある(図 8 )。この補強は, 主鉄筋量（曲げ耐力）が不 足している部分に対して曲げ補強を行って，地震力に抵 抗するう法である。

\section{$2 \cdot 3$ 橋脚の耐震補強}

橋脚には主鉄筋の量を少なくした部分（“段落し部” という) が設けられているものがありこのような橋脚

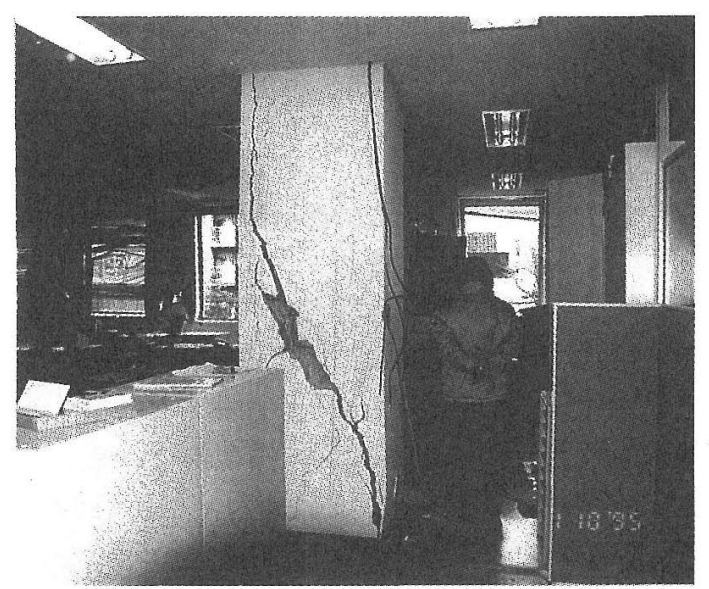

図 5 建築の柱の破壊例

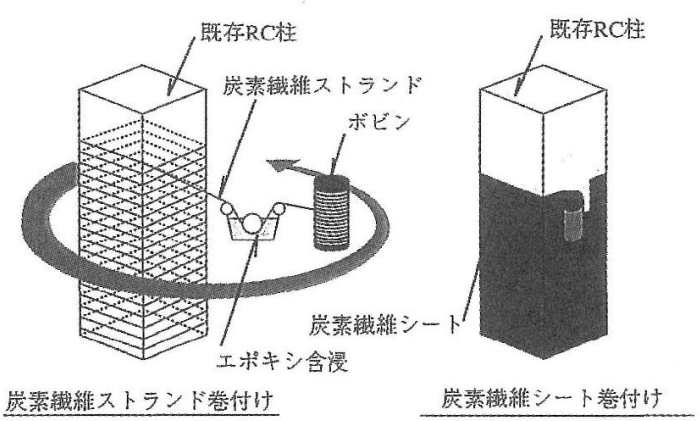

図 6 既存建築の柱の耐震補強上法 


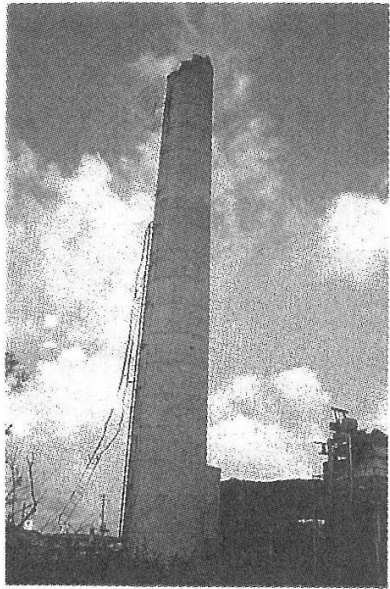

図 7 煙突の破壊例

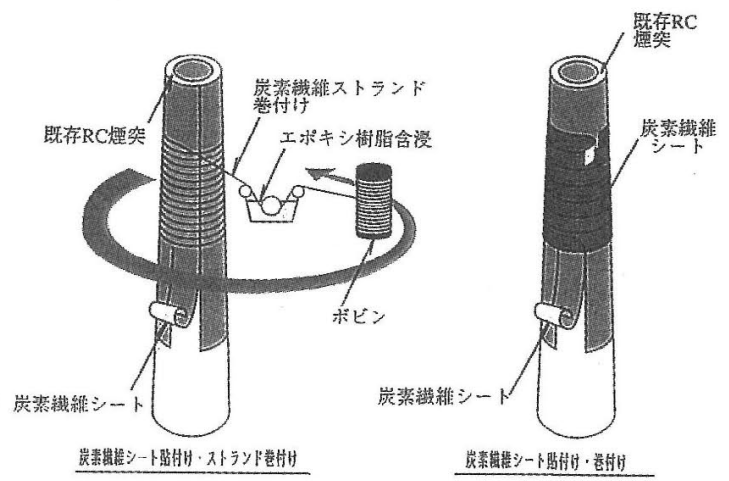

図 8 既存煙突の耐震補強工法

は段落し部が破壞する場合がある（図 9 )。橋脚の耐震 補強は，段落し部のコンクリート表面に，炭素纎維シー 卜を貼り付けて前記 (b) の曲げ補強を行う。さらに, 段 落し部と基部の部材軸と直角方向にも, 炭素瀻維シート または炭素繊維ストランドを巻き付けて，前記 (a)のせ 儿断補強を行う方法である(図 10)。この補強は，段楁 し部の曲げ破壞および段落し部と基部のせん断破壞を防 止することによって，基部を曲げ破壊させて柱を大きく 変形させ地震力に抵抗する方法である。

\section{$2 \cdot 4$ 耐震補強工法の特徵}

CFRP による既存構造物の耐震補強工法は, 他の工 法と比較して, 次のような特徴がある.

(1) 補強による重量の増加が少ない。

(2) 執務空間を区切らず，外観を損なわない.

(3) 補強作業が容易で，その信頼性も高い.

(4) 作業員に特殊な技能や資格が不要である。

(5) 補強による柱断面の増加がない.

(6) 錆びない補強材のため, 耐久性が向上する.

(7) 短い期間で補強工事が可能である。

(8) 重機が不要で狭い場所で施工が可能である.

(9) 煙突の場合操業を停止しないで補強できる。

\section{$2 \cdot 5$ 耐震補強工法の施工要領}

CFRPによる耐震補強工法の施工は，前述した建築 の柱 (せん断補強)，煙突（曲げ補強），掠よび橋脚（曲 げ補強とせん断補強）によって一部異なるが，基本的に

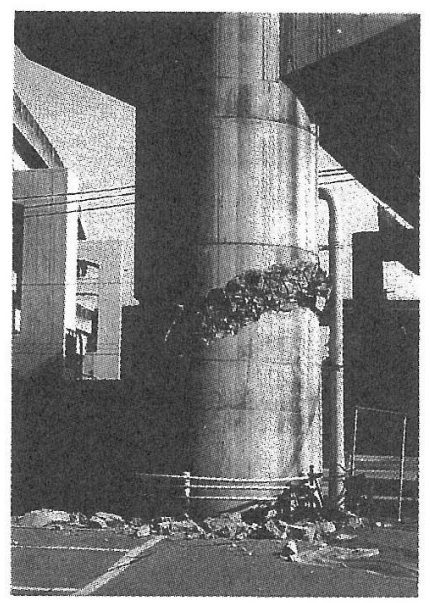

図 9 橋㑢の損傷例

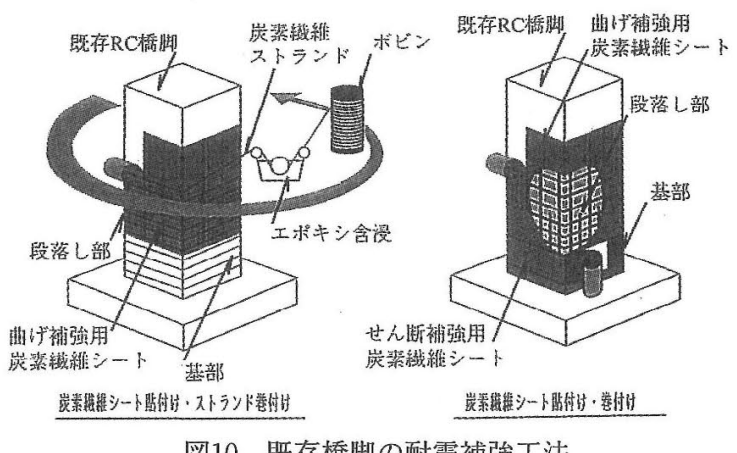

図10 既存橋脚の耐震補強工法

は次の手順となる。

(1) 既存仕上げや補強障害物の撤去や移設

(2) コンクリートの補修や下地処理, 矩形断面の場合 には，隅解部の丸みづけ(“面取り”) も行う。

(3) コンクリート表面への樹脂（プライマー）塗布

(4) 炭素纎維シートの貼り付け（曲げ補強）

(5) 炭素繊維ストランドまたは炭素繊維シートの巻き 付け(せん断補強)

(6) CFRP 表面の仕上げ

(7) 撤去した補強障害物の復旧

これらの通常の施工内容は，次のようである。

(1) 下地処理工事

CFRP が所要の強度を発揮するように，コンクリー 卜表面を調整する。CFRP は突起物に当たると非常に 折れやすいため，凹部を削り取って平滑にする。また， 表面の風化層を除去し, 凹部はモルタルで埋めて平滑に する、なお，コンクリートの有害なひび割れや浮き，錆 びた鉄筋は，それらを補修する。

(2) 隅角部の面取り工事

鋭角的な隅角部に巻き付けられた CFRPは, 所要の 引張強度を発揮する前に破断する. そのため, 矩形断面 の建築の柱や橋脚の場合には，隅角部に“面取り”を行 う。建築の柱では半径 $3 \mathrm{~cm}$ 以上, 橋脚では半径 $5 \mathrm{~cm}$ 以上としている。

(3) プライマー工事

コンクリートの表面を強化し，曲げ補強の炭素繊維シ 
ートとコンクリートとの接着力を向上させるために，樹 脂を塗布する。この際，コンクリート表面が十分乾燥し ていることを確認する必要がある.

（4）炭素纎維シート貼り付け（曲げ補強）工事 必要枚数の炭素繊維シートを，エポキシ樹脂を主成分 とする含浸・接着樹脂を用いて, 手作業で順次貼り付け て積層する (図 11). 含浸・接着樹脂は, 炭素繊維シー 卜の内部に浸透して CFRP 化させる纎維結合剂の役目 と, シートをコンクリート表面に接着させる接着片の役 目を兼ねるものである。

（5）炭素䋐維の巻き付け (せん断補強) 工事

炭素繊維ストランドの巻き付けは, “自動巻き付け機 械”によって施工寸る。建築の柱の施工状沉を図 12 に 示すが，高い煙突の場合には，ゴンドラと一休の巻き付 け機械を使用している。自動巻き付け機械による施工は, 品質管理が容易で省力化・工期短縮が可能となり, コス トダウンを図れるなどのメリットがある。一方，炭素繊 維シートを巻き付ける場合には，曲げ補強工事と同じ含 浸・接着樹脂を用い，また，貼り付ける場合と同じ要領 で, 必要枚数の炭素纎維シートを巻き付ける.

(6) 仕上げ工事

CFRP に含まれているエポキシ樹脂が火災時に燃焼 することや，保護・仕上げの観点から表面の仕上げを行 う。特に建築の柱の場合には，“防火性能”または“耐火 性能”を確保する被覆が必要となる。紧に対しての延 焼を防止する防火被覆または，火災中にCFRPを守る ための耐火被覆を設置する。

\section{CFRP の材料諸特性と品質管理 \\ $3 \cdot 1$ CFRP の引張特性}

CFRP の断面は, 炭素纎維と樹脂で構成されている が，炭素瀻維のみが引張強度を発揮し，樹脂はそれを助 ける役目を果たす。そのため，CFRP の引張強度は， 炭素纎維の量やそれ自体の引張强度, シート成形法の違 いによって決まることになる。また，同じ引張强度の炭 素繊維の場合には，断面内に含まれる繊維の量(“繊維 率”）によって決まる。プレストレストコンクリートに 用いるストランドや，鉄筋コンクリートに用いる鉄筋の 代替などとして使用される CFRP は，工場で生産され るため瀻維率がほぼ一定となる。しかし，既存構造物の

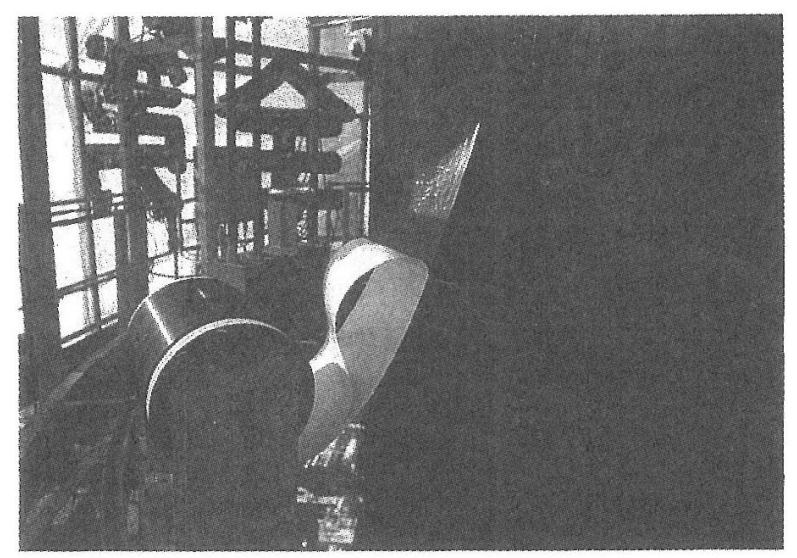

図11 炭素䋐維シートの㙋り付け
耐震補強工法に用いるCFRP は，現場での施工時に製 造することになるため，繊維率が一定とならない。その ため，補強工法の研究や設計に㧍ける CFRP の材料特 性は，その断面内に含まれる炭素瀻維断面積のみで，評 価するのが一般的となっている。この節では，CFRP の引張特性の評価法と品質管理の概要を述べる.

(1) CFRP ストランド

炭素繊維ストランドは，連続瀻維を束ねて糸状にした ものである。これを用いる補強では，必要量の炭素繊維 を巻き付けて，所要の強度を確保することになる，束ね る繊維の本数が多くなる程，ストランド 1 本あたりの引 張強度が高くなり，巻き付ける回数が少なくなるた施 工時間を短縮でき有利となる。しかし，施工時に樹脂が 炭素繊維ストランドに十分含浸し, 全断面がCFRP 化 できることを確認する必要がある。

ここでは，通常用いている炭素䋐維の素線を 1 万 2 千 本束ねた CFRP ストランド（断面積 $0.46 \mathrm{~mm}^{2}$ ）の引張 特性について述べる。引張試験は, JIS R7601「炭素繊 維試験方法（図 13）」に基づいて行なっている。な扔, 試験片の断面積が大きい場合には，後述の多積層 CFRP シートの試験法に準じて行うことになる.

CFRP ストランドの引張強度（破断時の強度）の試 験結果（試験片合計 67 本）は，平均値 $2.99 \mathrm{GPa}$, 標準 偏差 $0.15 \mathrm{GPa}$ である。また, 弾性係数の試験結果は, 平均値 $224 \mathrm{GPa}$ ，標準偏差 $15 \mathrm{GPa}$ であった。

CFRP ストランドによる耐震補強の設計では, 地震 時の荷重に対して，柱や橋脚のせん断破壞を防止するた めに必要な，CFRP ストランドの巻き付忖量を算定す る。この算定に用いる CFRP ストランドの設計用引張 強度は次式で求めている。

$$
K_{1} \times\left[\text { 平均値 }-K_{2} \times \text { 標準偏差 }\right]
$$

平均伯は CFRP 破断時の引張強度で, 係数 $K_{1}$ はせ 儿断耐力に対する利用率 (有效保数) である。また, 係 数 $K_{2}$ は引張強度の信頼係数で，2（不良率 $2.5 \%$ ）ま

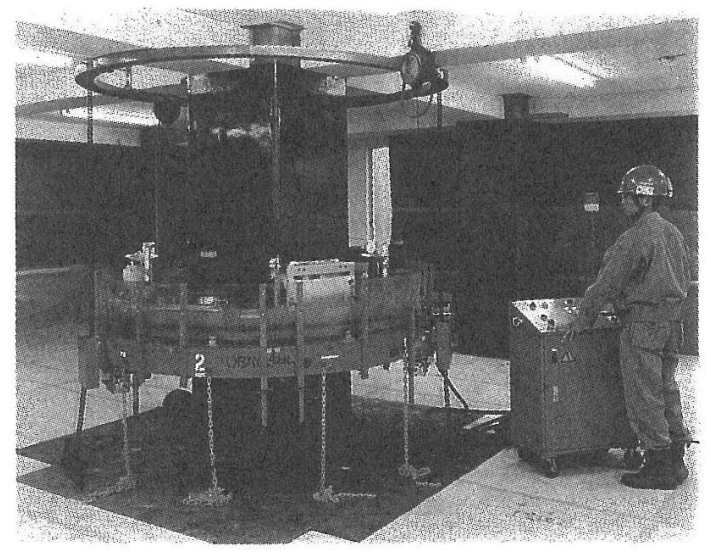

図12 炭素瀻維ストランドの巻き付け

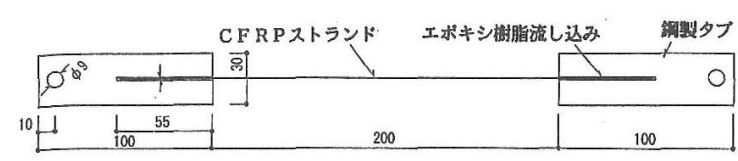

図13 CFRP ストランドの引張試験片 
まは 3 （不良率 $\fallingdotseq 0 ） と し て い る ， K_{1}$ は，主に実験結果 に基づくことになるが，使用環境条件や施工性なども加 味して決めている. $K_{1}$ と $K_{2}$ 両係数を関連づけて決める 必要もあり, $K_{2}=2$ で $K_{1}=2 / 3, K_{2}=3$ で $K_{1}=3 / 4$ と している例もある。この場合の設計用引張強度は 1.80 $\mathrm{GPa}$ 程度となる.

\section{(2) CFRP シート}

炭素繊維シートは，連続繊維を一方向に敷き並べてシ 一ト状にしたものである。エポキシ樹脂を含浸させたも の（以下，UD プリプレグ）と, 含浸させていないもの に大別される．後者は，ガラス繊維でクロス状に編んだ もの（以下，UD クロス）やガラス繊維を張り付けたも の（以下，UD シート）など，特殊な紡織技術でシート 状にしたものでいろいろな製品がある。これらの炭素繊 維シートは, 単位 $\mathrm{m}^{2}$ 当たりの炭素繊維量 (“目付量” という) で区別される。

炭素㵶維シートを用いる補強では, 必要枚数のシート を積層して所要の引張強度を確保することになる. 目付 量が多い程必要枚数が少なくなるため施工上有利となる が, 目付量が多くなると，樹脂を含浸させるのが難しく なる．施工時に樹脂を容易に含浸できる範囲で目付量は 多い程よいことになる，炭素繊維シートに樹脂を容易に 含浸でき，十分 CFRP 化できる目付量を検討する必要

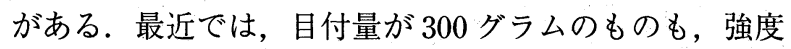
を確保することができるようになり，一部用いられ始め ている.ここでは，目付量が 175 グラムまたは 200 グラ ムの炭素繊維シートについて述べる.

CFRP シートは, 炭素纎維シートを必要枚数積層し たものである．積層数としては，3〜 5 層以内で使用さ れる場合が多いが，10層となる場合もある。それらの 厚さは, 炭素繊維シート 1 層の目付量と, メーカーの公 称值による炭素繊維断面積のみで求めている.

CFRP シートの引張試験は, JIS K7073「炭素繊維 強化プラスチックの引張試験方法 (図 14)」に準拠して 行なわれている.この方法で試験できる積層数は, 目付 量が 200 グラム程度の場合， 5 層前後までである．積層 数が多い場合には，他の方法で試験する必要があるが,

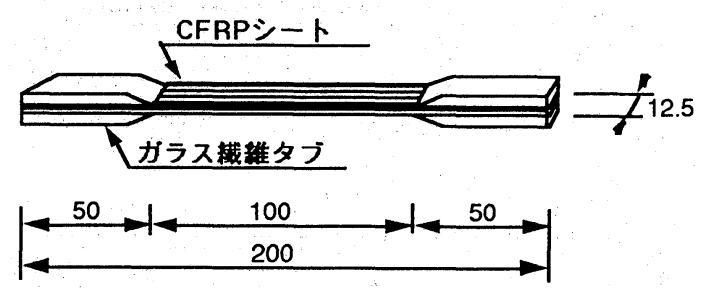

図14 積層数が少ない CFRP シートの引張試験片

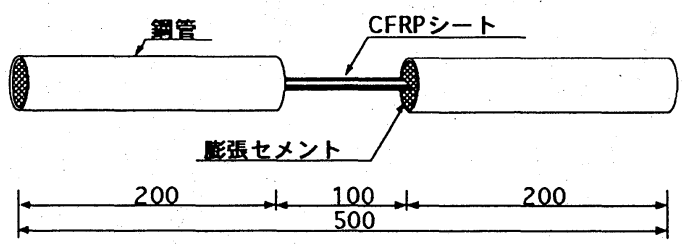

図15 積層数が多いCFRP シートの引張試験片
試験片の例を図 15 に示す。この試験片は, 試験する CFRP シートの両端部を鋼管の中央に設置し, 両者の 空隙に膨張セメントを充填するものである. なお，この 方法は，CFRP ストランドの断面積が大きい場合にも 採用されている.

前述した 3 種類の炭素繊維シート 1 層で製作した, CFRP シートの引張試験結果一覧を表 I に示す。引張 強度（破断時の強度）の平均值は，3.17 $\mathrm{GPa}, 2.90$ $\mathrm{GPa}$, および $4.07 \mathrm{GPa}$, 弾性係数の平均值は, 241

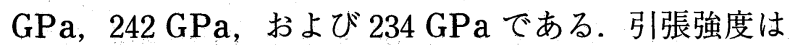
炭素繊維シートの違いで差があるが, 弾性係数は 3 種類 とも近似した值となっている.

炭素繊維シートを 1 層〜 10 層積層した 3 種類の CFRP シートの引張試験を, 引張強度と弾性係数を把 握することを目的として行った。試験片は，積層数が 1 〜 6 層は図 14，10 層は図 15 とした。試験結果について， 積層数と引張強度との関係を, 図 16 に示す. プロット した值は試験片 5 本の平均である。

この図から, 積層数の違いによる引張強度の顕著な差 はないことが分かる．この結果から，1１0 層を積層 した CFRP シートの単位断面積当たりの引張強度はほ ほ同じで，1層の試験によって評価することができると いえる.なお, CFRP シートの弾性係数も, 引張強度 と同じような試験結果であった。

CFRP シートによる耐震補強の設計では，地震時の 荷重に対して安全になるように使用量を算定する。すな わち, 柱や橋脚のせん断破壊, または煙突や橋脚の曲げ 破壊を，それぞれ防止するために必要な貼り付け量を算 定する。これらの算定に用いる CFRP シートの設計用 引張強度は, 式 (1)に基づき前述した CFRP ストラン ドと同じように決めている.

\section{$3 \cdot 2$ CFRP シートの付着性状}

CFRP による耐震補強工法における曲げ補強は，コ

表 I CFRP シートの引張試験結果の一覧

\begin{tabular}{|c|c|c|c|c|c|c|}
\hline \multirow{2}{*}{$\begin{array}{l}\text { 炭素繊維シ } \\
\text { 一トの種類 }\end{array}$} & \multirow{2}{*}{$\begin{array}{l}\text { 目付量 } \\
\text { グラム }\end{array}$} & \multirow{2}{*}{$\begin{array}{c}1 \text { 層の厚さ } \\
\mathrm{mm}\end{array}$} & \multicolumn{2}{|c|}{ 引張強度 $\mathrm{GPa}$} & \multicolumn{2}{|c|}{ 弾性係数 GPa } \\
\hline & & & 平均値 & 標準偏差 & 平均値 & 標準偏差 \\
\hline UD プリプレグ & 175 & 0.0972 & 3.17 & 0.24 & 241 & 11 \\
\hline UDクロス & 200 & 0.115 & 2.90 & 0.15 & 242 & 6 \\
\hline UD シート & 175 & 0.0972 & 4.07 & 0.23 & 234 & 15 \\
\hline
\end{tabular}

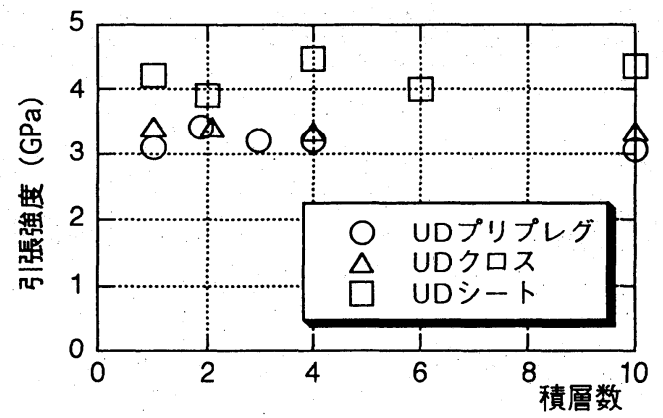

図16 積層数 引張強度関係 
ンクリート表面に炭素繊維シートを貼り付けて行うもの である．曲げ補強効果を発揮するためには，CFRP シ ートとコンクリートとが一体化し，それらの界面での付 着力が十分あることが必要となる.この節では, “接着 試験”および “付着試験”について述べる.

(1) 接着試験

CFRP シートとコンクリートとの一体性（接着性） を確認する試験で, JIS A6909「薄付け仕上げ塗料の付 着強さ試験」に準拠して行っている．試験は，図 17 に 示すように, $40 \mathrm{~mm} \times 40 \mathrm{~mm}$ で厚さ $10 \mathrm{~mm}$ の鋼製治具 を CFRP シートの表面に貼り付け，その治具を引張る ことによって行う. CFRP シートの断面内やコンクリ ートとの界面で破壊しないで，コンクリート内で破壊し たものが良好な結果である. 接着強度は, 破壊時の引張 力を接着面積で割って求める.

接着強度はコンクリートの圧縮強度によって決まるこ とになり, 圧縮強度が $30 \mathrm{MPa}$ 程度の場合, 接着強度 は $0.9 \mathrm{MPa} \sim 1.6 \mathrm{MPa}$ となる.この試験は, CFRP シ 一トとコンクリートとの接着性に関する, 施工時の品質 管理に利用することができる.

\section{(2) 付着試験}

コンクリートに貼り付けた CFRP シートに引張力が 作用した場合の, 付着面での強度 (付着強度) の把握を 目的とする試験である. 現在試験法に関する JIS 規定 がないため, 考案したのが図 18 に示す試験片である.

CFRP シートの付着長さと炭素繊維シートの種類を試 験パラメーターとして行った試験の結果について, 付着 長さと最大引張力との関係を図 19 に, 付着長さと最大 付着応力度との関係を図 20 に，それぞれ示す。最大付 着応力度は, 最大引張力を付着面積で割った值である. なお, 試験時のコンクリート圧縮強度は $38.6 \mathrm{MPa}$ であ

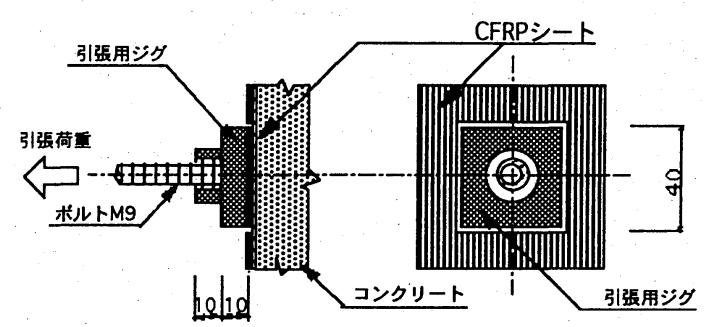

図17 CFRP シートの接着試験方法

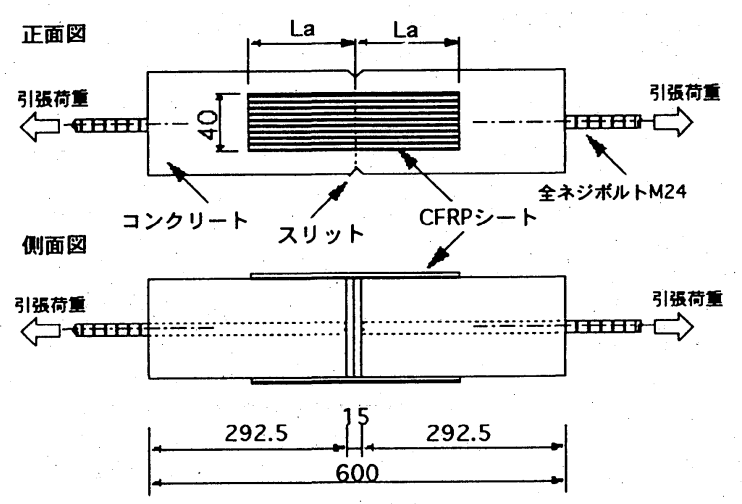

図18 CFRP シートの付着試験体
る.

最大引張力（付着面のせん断力）は, 炭素繊維シート の違いで多少の差異があるが, ほぼ一定の值となってい る. また, 最大付着応力度 (付着強度) は, 付着長さが 長くなるに従って低下しており, 付着長さが $30 \mathrm{~cm}$ の 場合には, $0.5 \mathrm{MPa} \sim 0.6 \mathrm{MPa}$ となっている.

以上に述べた付着試験や接着試験, 次節で述べる耐久 性試験の結果, および CFRP シートで曲げ補強した部 材の実験結果に基づいて, 設計で使用する付着強度を決 めている. なお, 接着試験は, 施工時の品質管理や補強 後の構造上の安全性確認の資料としている.

\section{3・3 CFRP シートとその接着面の耐久性}

CFRPによって耐震補強した構造物は，長期間使用 することになるため, CFRP および CFRP とコンクリ 一トとの接着面の耐久性が問題となる。これらの耐久性 は，促進暴露試験と屋外暴露試験で検討されている。 こ の節では, 促進暴露試験について述べる.

促進暴露試験は, JIS A1415「プラスチック建築材料 の促進暴露試験方法」に基づく, サンシャインカーボン タイプのウエザーメーターを用いている. CFRP シー 卜の耐久性は，図 14 に示した試験片の CFRP 部分の みを暴露した。 また， CFRP シートとコンクリート面 との接着面の耐久性は, 炭素繊維シートを貼り付けたモ ルタル板を暴露した.

CFRP シートの暴露時間と引張強度との関係を図 21 に，接着面の暴露時問と接着強度との関係を図 22 に, それぞれ示す。プロットした值は, 試験片 5 本の平均で ある。 これらの図から, CFRP シートおよび CFRP シ ートとコンクリート面との接着面の強度は, 炭素繊維シ 一トの違いで経過がやや相違しているが，2千時間の促

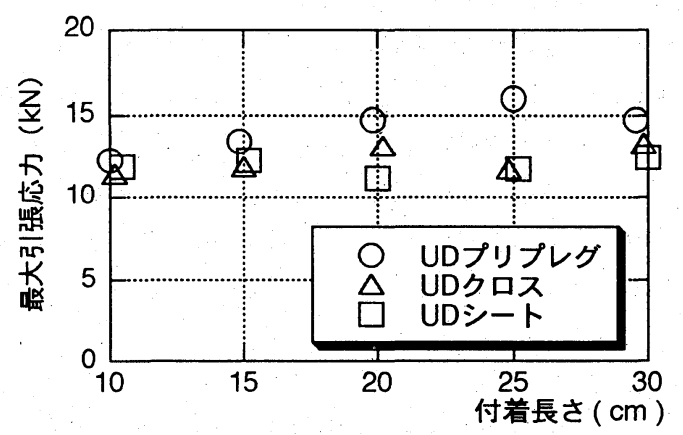

図19 付着長さ〜最大引張力関係

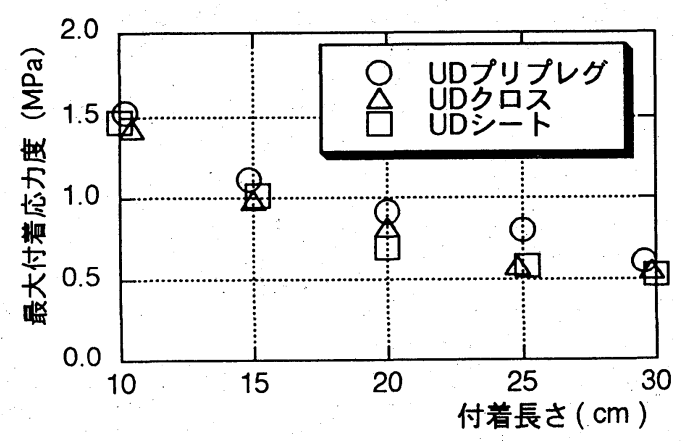

図20 付着長さ〜最大付着応力度関係 


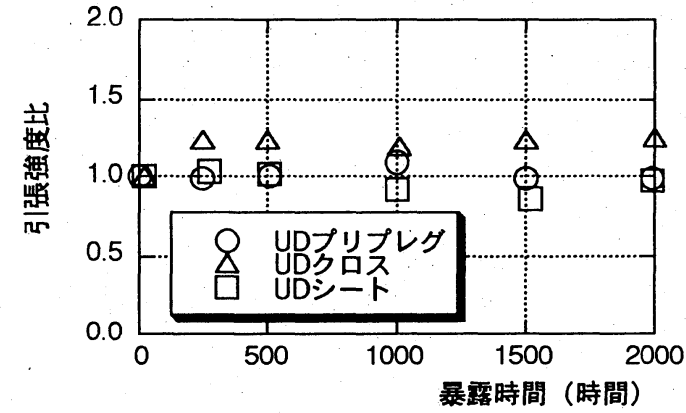

図21 促進暴露時間～引張強度関係

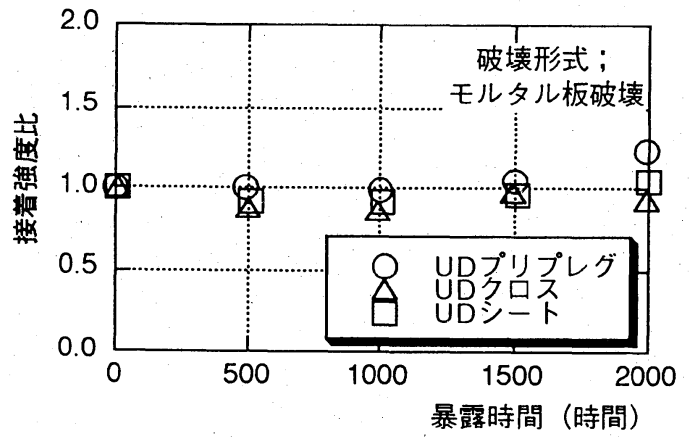

図22，促進暴露時間～接着強度関係
進暴露による顕著な強度の低下はないといえる，促進暴 露の時間と実構造物での年数との相関関係が十分解明さ れていないため, 屋外暴露または実構造物での試験結果 が重要となる. 最初に施工した煙突の耐震補強例では, 9 年経過した現在強度は低下していないが, 耐久性につ いては実構造物での検証を継続する必要がある.

$$
4 \text { あ と がき }
$$

CFRP による既存構造物の耐震補強について述べた が, この技術は橋梁の桁や床板, 建築の梁や床, 工作物 などの補強にも幅広く適用できる. 既存不適格構造物の 耐震補強は社会的要請であり, ここで述べた耐震補強工 法が貢献できるように，さらなる研究開発と改善が促進
されることが期待される.

\section{参，考 文 献}

1) 建設省建築研究所, 国土開発技術研究セン夕一監修, “建 設省総合技術開発プロジェクト，建設事業への新素材・新 材料利用技術の開発一非金属系分科会報告書”（1993）国 土開発技術研究センター。

2）連続繊維補強コンクリート編集委員会編, “連続䋐維補強 コンクリート[諸性質と設計法]”（1995）技報堂出版.

3）侏 大林組, “CRS 工法による既存鉄筋コンクリート柱の 耐震補強工法一設計・施工指針一”（1995）CRS 研究会. 